\title{
Factors Influencing High School Students to Persist in Aspirations of Teaching Careers
}

Wei-Cheng J. Mau, Yun-Hwa Mau

\begin{abstract}
This study longitudinally tracks 10th grade students for 4 years regarding their persistence in aspirations of teaching careers using a nationally representative sample (National Educational Longitudinal Survey of 1988). Factors contributing to persistence in aspirations of teaching careers are examined based on the social-cognitive career theory (SCCT). Results suggest that there are racial differences in persistence in aspirations to teaching careers. Students who persist perform better on academic achievement, score higher on locus of control, and come from a family that had a higher socioeconomic status and a higher parental education level than students who do not persist. Results also suggest a good fit of the socialcognitive model in prediction of persistence in teaching aspirations.
\end{abstract}

Keywords: career choices; career persistence; teaching aspirations; high school students

\section{Characteristics of High School Students Who Persisted in Aspirations of Teaching Careers}

In many school districts, teacher shortages have reached alarming levels. According to Assistant Secretary Stroup's (2002; U.S. Department of Education, 2002) testimony before the House Subcommittee on Labor/Health and Human Services/Education Appropriations, America's schools will need to hire more than 2 million teachers during the next decade, more than half of whom will be first-time teachers. Statistical models also show that approximately 2.4 million newly hired public school teachers will be needed from 1999 to 2009 (U.S. Department of Education, 1999).

One way to address the teacher shortage problem is to use national database resources to identify individuals potentially seeking teaching careers, explore how they got interested, what plans they made, and whether they succeeded. Studies related to career aspirations and persistence have largely focused on investigating why an individual chooses a career in teaching, why teachers change positions, and what causes teachers to leave the profession (e.g., Grissmer \& Kirby, 1997; Henke \& Zahn, 2001; Ingersoll, 2001; Shen, 1997). Lack of systematic inquiries and extended follow-ups on this issue appear to be critical and can be best addressed through analysis of national databases. More important, lack of study examining the shortage of underrepresented minority teachers prompted this investigation. To the best of our knowledge, this study represents the first attempt to use cognitive social theory as a framework to examine the career interests and persistence of students who aspire to K-12 teaching careers.

Many theorists have stressed the importance of interests and career aspirations in young people's career development (e.g., Holland, 1997; Super, Savickas, \& Super, 1996; Tracey, Robbins, \& Hofsess, 2005). Studies have indicated that decisions to become teachers can be traced back to middle school years (Lee, Clery, \& Presley, 2001; Page \& Page, 1984) and likely peak at ages 15 to 16 (Page, Page, Hawk, Amburgey, \& Correro, 1980). Tracey et al. (2005) suggested that high school years are a time of focus for career interventions because students' career interests begin to stabilize. Hence, the present study focused on 10th grade students who say they want to be teachers and longitudinally examined how their career choices in teaching unfolded through their college years.

Research has shown the strength of young people's career aspirations in predicting their subsequent career behaviors (Hansen, 2005; Mau \& Bikos, 2000). Because of the critical nature of students' aspirations, researchers (e.g., Anderson, 1992; Farmer, Wardrop, Anderson, \& Risinger, 1995; 
Fouad \& Smith, 1996; Hanson, 1994; W. L. Lent, Brown, \& Hackett, 1994; Mau, 2003; Mau \& Bikos, 2000; Wilson \& Wilson, 1992) have turned toward determining the relative value and importance of the various factors theorized to determine and shape those specific aspirations. For example, Mau (2003) used a logistic regression model to determine the relative importance of these variables in explaining persistence in science and engineering aspirations. As shown in Mau's study, men are more likely than women to persist in science or engineering career aspirations. His study has also shown that self-efficacy was among the strongest predictors of persistence in science and engineering careers. Informed by social-cognitive career theory (SCCT; W. L. Lent et al., 1994), Mau and Bikos (2000) identified four clusters of variables that significantly predicted the occupational aspirations of minority and female students. These clusters are personal and psychological characteristics, family variables, school experiences, and race and gender.

In this study, we used social SCCT as our conceptual framework to under-stand factors influencing high school students to persist in aspirations to teaching careers. This model concerns itself with the effects of self-efficacy beliefs, expected outcome and goal mechanisms, and how these variables interrelate with gender, contextual, experiential, and learning factors. According to the SCCT (R. W. Lent, Brown, \& Hackett, 1996), personal career-related behavior is influenced by four aspects: (a) behaviors, (b) self-efficacy beliefs, (c) outcome expectations, and (d) goals, in addition to genetically determined characteristics. Goals are considered the key organizational processes that influence an individual's thoughts and behaviors (Schutz, Crowder, \& White, 2001). Self-efficacy serves as a generative mechanism through which individuals integrate and apply their existing cognitive, behavioral, and social skills to a task. SCCT posits that self-efficacy affects thought patterns and partly determines individuals' actions and their decisions to engage in a task, to put forth effort, and to persevere under failure (Bandura, 1986). Self-efficacy expectations refer to a person's beliefs regarding "career-related behaviors, educational and occupational choice, and performance and persistence in the implementation of those choices" (Betz \& Hackett, 1997, p. 383).

According to Lent (2005), persistence can be seen both as a matter of choice stability, involving the decision to remain at or disengage from a particular activity (e.g., education tasks, job positions, or careers), and as an indicator of how well an individual is performing at either required or chosen endeavors. From the perspective of educational and work environments, persistence is considered a sign of performance adequacy because it is assumed that competent performers will persist longer, enabling attainment of educational milestones and job tenure. In this study, we tracked 10th graders for 4 years regarding their career aspirations. Students who persist in teaching aspirations are defined as those whose aspirations to $\mathrm{K}-12$ teaching careers remain unchanged after 4 years. Our focus was on $\mathrm{K}-12$ teaching careers; persistence and shifting aspiration from K-12 to postsecondary teaching were excluded from our analyses.

Specifically, students who persisted were compared to students who did not persist with regard to their self-concept, parental expectations and educational involvement, socioeconomic status (SES), and academic achievement. A logistic regression model was used to predict persistence in teaching aspirations.

Specifically, we examined

1. characteristics of students who persisted in their teaching career aspirations

2. gender differences in persistence in teaching aspirations

3. race differences in persistence in teaching aspirations

4. important predictors of persistence in teaching career aspirations. 


\section{Method}

Participants

The data used in this study were based on the National Educational Longitudinal Survey of 1988 (NELS: 88), which consists of a base year (1988), first follow-up (1990), second follow-up (1992), third follow-up (1994), and fourth follow-up (2000). NELS: 88 is the most recent series of longitudinal studies designed to provide trend data about critical transitions experienced by students as they progress through high school and into college or their careers. The base year survey comprised a nationally representative sample of 24,599 students selected from 1,052 middle schools (public $n=815$ and private $n=237$ ) in the United States. The sample was stratified by school size, urban versus rural, region, and percentage of minority students (National Center for Educational Statistics, 1994). Because of student dropouts, the sample was refreshed with additional students in both the first follow-up (10th grade $N=20,840$ ) and second follow-up $(12$ th grade $N=21,188)$. The third follow-up $(N=14,915)$ took place in the spring of 1994, when most sample members had been out of high school for 2 years. This study was based on the first follow-up and the third follow-up surveys, covering a 4-year period.

\section{Variables}

Students who participated in the NELS: 88 completed a 45-min self-administered questionnaire in their classrooms (National Center for Educational Statistics, 1991). The questionnaire was designed to collect information about a wide range of topics, including students' and parents' backgrounds, perception of self, students' educational and vocational activities, postgraduation plans, and aspirations. Students also completed an 85-min battery of cognitive tests (reading, mathematics, science, and social studies).

Independent variables. Four clusters of independent variables included in this study were as follows:

1. Self-efficacy variables

Self-concept. This variable was measured by a composite score consisting of seven self-concept items (e.g., "I feel good about myself"). Cronbach's alpha estimated for 13,514 10th graders is .95 .

Locus of control. This variable was measured by a composite score derived from six locus of control items (e.g., "I don't have enough control over the direction my life is taking"). Cronbach's alpha estimated for 13,514 10th graders is .94 .

Academic self-efficacy. This variable was measured by five survey questions (e.g., "math is one of my best subjects," "English is one of my best sub-jects"). Cronbach's alpha estimated for 11,990 10th graders is .75.

2. Home environment and familiar variables

SES. SES is a composite score that was based on parents' education, parents' occupation, and family income. Parental education ranged from 1 (did not finish high school) to $6(P h D, M D$, or other postgraduate degree). Occupational data were coded using the Duncan Socioeconomic Index Scale. Family income data were based on the total family income in 1987. Income level ranged from 1 (none) to $15(\$ 200,000$ or more). Each component was standardized with a mean of 0 and a standard deviation of 1 . All components were averaged yielding the SES composite. The composite scores were then recoded into quartiles.

Perceived parental expectations. This variable was measured by the survey question "How far in school do you think your father and your mother want you to get?" Responses were coded from 1 to 6 as follows: $1=$ won't finish high school, $2=$ will graduate from high school, $3=$ will go to vocational school, $4=$ will attend college, 5 $=$ will graduate from college, and $6=$ will attend a higher level of school after 
graduating from college. Students recorded their perceptions for each parent separately. A total score was used.

Parental school involvement. This variable was measured by the survey question "In the first half of the school year, how often did either of your parents or guardians do any of the following?" Responses were as follows: (a) "attend a school meeting," (b) "attend a school event in which you participated," (c) "phone teacher or counselor," or (d) "act as a volunteer at your school." Cronbach's alpha estimated for 11,150 10th graders is .65 .

Parental academic involvement. This variable was measured by the survey question "In the first half of the school year, how often have you discussed the following with either or both of your parents or guardians?" Responses were as follows: (a) "selecting a course or program at school," (b) "school activities or events of particular interest to you," (c) "things you have studied in class," (d) "your grades," (e) "transferring to another school," (f) "plans and preparation for the ACT or SAT tests," or (g) "going to college." Cronbach's alpha estimated for 13,514 10th graders is .97.

Number of siblings. This variable was derived from the base year parent survey questionnaire and indicated the participant's household composition (Famcomp).

3. School and academic variables

School variables included high school program (general, academic, and vocational and technical program), school setting (urban, suburban, and rural), school size, and school type (public or private/parochial schools).

Academic proficiency was measured by a composite score of two cognitive tests developed by Educational Testing Service [mathematics (40 items) and reading (21 items)]. The reading test consisted of five short passages followed by comprehension and interpretation questions. The mathematics test consisted of quantitative comparisons and other questions. A standardized composite score $(M=50, S D=10)$ was used. Coefficient alpha reliabilities on the eighth grade sample for the math and reading tests were .90 and .84 , respectively. Based on the Mantel-Haenszel odds-ratio analyses (Holland \& Thayer, 1986), there was little evidence of differential item functioning for either gender or racial/ethnic group. Factor analytic results supported the discriminant validity of the three content areas. Convergent validity also was indicated on the hypothesized factors. More detailed psychometric information can be found in the National Center for Educational Statistics' (1991) Psychometric Report.

4. Sex and ethnicity variables

Four major race groups were included: Asian, Hispanic, Black, and White American. Insufficient numbers of Native Americans included in the sample precluded them from the statistical analysis.

Dependent variables. The dependent variable was measured based on the status of students' career aspirations (occupation expected at age 30) at different career transition points. The dependent variable was further coded as (a) persisters (students who aspired to a teaching career both at 10th grade and 4 years later) and (b) switchers (students who aspired to a teaching career at 10th grade but changed their expectations to nonteaching careers). 


\section{Data Analyses}

The research questions proposed earlier were addressed by several separate statistical analyses. First, 10th graders who initially aspired to the teaching profession and persisted in the follow-up cohort were identified and profiled using descriptive statistics and frequencies. Separate analyses of variance (ANOVAs) were performed to provide further understanding of the nature of persistence factors. Second, factors contributing to persistence in a teaching career were analyzed using logistic regression analysis. Logistic regression was used to test the probability that members of a specific group are more likely to persist in pursuing a teaching career. Variable selection and entry into the model were guided by the SCCT of career choice and aspiration. Predictors were entered in blocks simultaneously, with demographic variables entered first, then school variables, followed by family variables, and psycho-logical variables. Logistic analysis provides a global test for the significance of a given predictor controlling for all other predictors in the model, as well as a test for the significance of a set of predictors. The analyses were based on weighted samples created to adjust for the oversampling bias that redistributed the observations to represent the distribution in the population (National Center for Educational Statistics, 1997). Because statistical procedures generally compute regression coefficients based on simple random sample assumptions, the standard errors must be adjusted with the design effects using appropriate variance estimation procedures to take into account the complex sampling procedures used in the NELS: 88 surveys (Curtin, Ingels, Wu, \& Heuer, 2002). AM Statistical Software Beta Version 0.06.02. (Cohen, 2005) was used in this study to adjust for standard errors for significant tests.

\section{Results}

Initial analyses indicate that of 20,840 10th grade students, 451 aspired to teaching careers. Four years later, 183 remained aspired to teaching careers (persisters), and 268 lost their interest (switchers). Chi-square analyses were conducted to examine differences in percentages of students who persisted in teaching aspirations as a function of sex and race. Results showed significant differences in persistence of teaching aspirations as a function of race, $\chi^{2}(3)=9.98, p<.021$. As seen in Table 1 , White (42\%) and Hispanic (43\%) students were more likely than Asian (0\%) or Black (25\%) students to persist in teaching career aspirations. Chi-square analyses did not show a significant difference as a function of sex, $\chi^{2}(2)=$ $2.59, \mathrm{p}<.11$.

One of our major interests was to determine if persisters differed from switchers in characteristics as conceptualized by the SCCT (R. W. Lent et al., 1996). Results are summarized in Table 2. Results of oneway ANOVAs showed significant differences between persisters and switchers in academic proficiency, $F(1,441)=16.22, p<.000$, locus of control, $F(1,445)=5.89, p<.016$, parents' educational level, $F(1,439)$ $=23.37, p<.000$, and SES, $F(1,443)=20.55, p<.000$. Post hoc analyses indicated that persisters scored significantly higher than switchers on academic performance, parental educational level, and SES and had a higher internal locus of control.

A logistic regression analysis was conducted to identify important predictors of students who persisted in teaching aspirations. Results showed significant improvement in the fit of the model when demographic variables, $\chi^{2}(4)=4.13, p<.003$, school variables, $\chi^{2}(15)=2.49, p<.002$, and family variables, $\chi^{2}(21)=29.30, p<.000$, were added to the model. Of special interest were the effects of self-efficacy variables, which were entered last in the model. Significant improvement was found after their addition, $\chi^{2}(25)=34.78, p<.000$. 
Table 1

Sex and Race Differences in Persistence in Teaching Aspirations

\begin{tabular}{lrrrrr}
\hline & \multicolumn{2}{c}{ Persister $(N=183)$} & & \multicolumn{2}{c}{ Switcher $(N=268)$} \\
\cline { 2 - 3 } \cline { 5 - 6 } & \multicolumn{1}{c}{$n$} & & & $n$ & $\%$ \\
\hline Boys & 31 & 33 & 62 & 67 \\
Girls & 152 & 44 & & 206 & 56 \\
Asian & 0 & 0 & & 6 & 100 \\
Hispanic & 10 & 43 & 21 & 57 \\
Black & 7 & 25 & & 13 & 75 \\
White & 163 & 42 & 224 & 58 \\
\hline
\end{tabular}

Note: Of the 451 10th grade students who initially aspired to a teaching career, 183 reported that they remained interested in a teaching career 4 years later (persister), whereas 268 had changed their aspirations to other careers (switcher). Several cases were excluded in the analysis of racial difference because of insufficient numbers or unreported ethnic information.

Table 3 contains the summary results of the logistic regression analysis. $\operatorname{Exp}(\beta)$ is the predicted change in odds for a unit increase in the predictor (Cizek \& Fitzgerald, 1999). An $\operatorname{Exp}(\beta)$ coefficient equal to 1.00 indicates no change in the odds of occurrence of the outcome and is associated with changes in the independent variable; a value of $\operatorname{Exp}(\beta)$ greater than 1.00 indicates that the odds of the outcome increase with changes in the independent variable; value of $\operatorname{Exp}(\beta)$ less than 1.00 indicates that the odds of the outcome decrease with changes in the independent variable. The Beta indicates the effect of the variable on the probability estimate of persistence in teaching aspirations. The higher the value, the greater impact the variable has on the dependent variable. The positive-negative sign of the value indicates the direction of prediction. Four variables emerged as the most powerful predictors: race, school setting, school type, and high school program. Specifically, as compared to White students, Asian American students were significantly less likely to persist in aspirations of teaching careers. To a lesser

Table 2

Differences in School, Familiar, and Personal Factors Among High School Students Who Aspired to Teaching Careers

\begin{tabular}{|c|c|c|c|c|c|c|c|}
\hline & \multicolumn{2}{|c|}{$\begin{array}{l}\text { Persisters } \\
(n=183)\end{array}$} & \multicolumn{2}{|c|}{$\begin{array}{l}\text { Switchers } \\
(n=268)\end{array}$} & \multirow[b]{2}{*}{$F$} & \multirow[b]{2}{*}{$p$} & \multirow{2}{*}{$\begin{array}{c}\text { Effect } \\
\text { Size }\end{array}$} \\
\hline & $M$ & $S D$ & $M$ & $S D$ & & & \\
\hline Math and reading proficiency & 54.90 & 7.2 & 51.5 & 9.9 & 16.22 & .00 & .39 \\
\hline Locus of control & 0.18 & 0.6 & 0.03 & 0.6 & 5.89 & .02 & .24 \\
\hline Self-concept & -0.04 & 0.7 & -0.02 & 0.7 & 0.07 & .79 & .03 \\
\hline Socioeconomic status & 0.34 & 0.7 & 0.04 & 0.7 & 20.55 & .00 & .44 \\
\hline Parental involvement & 2.96 & 1.9 & 2.80 & 2.0 & 0.57 & .45 & .08 \\
\hline Parental expectation & 5.83 & 0.7 & 5.78 & 1.1 & 0.21 & .64 & .05 \\
\hline Parents' educational level & 3.67 & 1.2 & 3.13 & 1.1 & 23.37 & .00 & .49 \\
\hline Math self-efficacy & 11.97 & 5.0 & 12.06 & 5.2 & 0.03 & .86 & .02 \\
\hline English self-efficacy & 8.90 & 2.9 & 8.65 & 2.7 & 0.88 & .35 & .11 \\
\hline
\end{tabular}


effect, Black and Hispanic American students were also less likely than White students to persist. Other factors being equal, students from the urban school setting were more likely to persist than those from rural or suburban settings. Students who enrolled in a vocational-technical program were the least likely to persist as compared to those in a regular academic program. One of our major interests is the role of self-efficacy in predicting career persistence. Although the proxy measures of self-efficacy are not statistically significant in predicting the persistence in teaching aspirations, they do increase the odds of the outcome. With all other predictor variables held constant, a one unit increase in self-concept is associated with a $46 \%$ increase in the odds of persisting in teaching aspiration. A one unit increase in locus of control score also associated with a $38 \%$ increase in the odds of persistence. English self-efficacy associated with a $12 \%$ increase, whereas math self-efficacy decreased about $2 \%$.

Table 3

Hierarchical Logistic Regression:

Predictors of Persistent Aspirations in Teaching Careers

\begin{tabular}{|c|c|c|c|c|c|}
\hline Variable & $B$ & $S E$ & $t$ & $p$ & $\operatorname{Exp}(\beta)$ \\
\hline \multicolumn{6}{|l|}{ Demographic variables } \\
\hline Males & -0.34 & 0.60 & -0.57 & .57 & 0.72 \\
\hline \multicolumn{6}{|l|}{ Race } \\
\hline Asian & -4.75 & 1.62 & -2.93 & .00 & 0.01 \\
\hline Hispanic & -0.25 & 0.76 & -0.33 & .74 & 0.78 \\
\hline Black & -0.72 & 1.06 & -0.68 & .50 & 0.49 \\
\hline \multicolumn{6}{|l|}{ School variables } \\
\hline Academic proficiency & 0.01 & 0.03 & 0.34 & .74 & 1.01 \\
\hline \multicolumn{6}{|l|}{ High school program } \\
\hline General & 0.10 & 0.40 & 0.26 & .80 & 1.10 \\
\hline Vocational or technical & -13.32 & 0.83 & -16.12 & .00 & 0.00 \\
\hline \multicolumn{6}{|l|}{ School type } \\
\hline Public school & -1.45 & 1.02 & -1.41 & .16 & 0.23 \\
\hline Catholic & -1.94 & 0.98 & -1.97 & .05 & 0.14 \\
\hline \multicolumn{6}{|l|}{ School setting } \\
\hline Urban & 2.06 & 0.64 & 3.21 & .00 & 7.05 \\
\hline Suburban & 0.00 & 0.43 & 0.00 & 1.00 & 1.00 \\
\hline \multicolumn{6}{|l|}{ School region } \\
\hline Northeast & -0.92 & 0.89 & -1.02 & .31 & 0.40 \\
\hline North central & 0.19 & 0.52 & 0.36 & .72 & 1.21 \\
\hline South & -1.05 & 0.55 & -1.93 & .06 & 0.86 \\
\hline School size & 0.06 & 0.10 & 0.63 & .53 & 1.06 \\
\hline \multicolumn{6}{|l|}{ Familial variables } \\
\hline Socioeconomic status & -0.60 & 0.48 & -1.27 & .21 & 0.55 \\
\hline Parents' educational level & 0.19 & 0.27 & 0.70 & .49 & 1.21 \\
\hline Parental homework involvement & -0.15 & 0.10 & -1.51 & .13 & 0.86 \\
\hline Parental school involvement & 0.06 & 0.09 & 0.69 & .49 & 1.06 \\
\hline Parental educational expectation & -0.03 & 0.15 & -0.21 & .83 & 0.97 \\
\hline Number of siblings & 0.03 & 0.11 & 0.26 & .80 & 1.03 \\
\hline \multicolumn{6}{|l|}{ Psychological variables } \\
\hline Self-concept & 0.38 & 0.41 & 0.92 & .36 & 1.46 \\
\hline Locus of control & 0.32 & 0.43 & 0.74 & .46 & 1.38 \\
\hline Math self-efficacy & -0.02 & 0.04 & -0.39 & .70 & 0.98 \\
\hline English self-efficacy & 0.11 & 0.07 & 1.65 & .10 & 1.12 \\
\hline
\end{tabular}

Note: Variables were entered in blocks based on social-cognitive career theory model. 
In summary, about $40 \%$ of 10 th grade students persisted 4 years after they initially aspired to a teaching career. For some reason, a great percentage of students dropped from their initial indication of interest in a teaching career. White students were more likely than minority students to persist. Students who persisted performed better on academic achievement, scored higher on locus of control, and came from a family that had a higher social economic status and a higher parental education level than students who did not persist. Although our findings suggest that our data fit the social-cognitive model, we find that school and demographic variables, in general, were more predictive than familial or self-efficacy variables.

\section{Discussion}

The present study used four clusters of variables to predict students' persistence in aspirations to teaching careers. The SCCT (Lent et al., 1996) was used as a theoretical framework to guide the variable selection procedure.

School variables in general were the most important factor of the four variable clusters in the model. It is interesting that academic performance has been identified as an important predictor from previous studies (e.g., Mau, 2003; Mau, Domnick, \& Ellsworth, 1995) but was found to have minimal predictive power in this study. We believe that students' academic proficiency may only influence persistence in certain career pursuits, such as science or engineering-related careers. It appears that academic proficiency is not a significant factor for students to persist in teaching careers.

It is unexpected that none of the family variables had a significant impact on persistence in teaching career aspirations. Although there were significant differences in parental educational attainment and SES between persisters and switchers, these variables were less potent in predicting teaching persistence in the model. Their unique contribution diminished when other variables were added to the model.

Putting all these factors together, perhaps the most comprehensive model explaining persistence of career aspiration can be attributed to the work of W. L. Lent et al. (1994). In their proposed SCCT, they explain how contextual support and personal input affect self-efficacy expectations, which in turn translate into career interests and career goals. In other words, if people perceive their efforts to be impeded by adverse environmental factors, such as inadequate support systems or an intimidating environment, their aspirations are less likely to be translated into goals and their goals into action. Aligning with this theoretical expectation, our findings suggested that students from urban school settings were more likely to persist than those from rural or sub-urban settings. Students who enrolled in a vocationaltechnical program were least likely to persist as compared to those in a regular academic program. Although none of the self-efficacy variables are statistically significant in predicting students' persistence in teaching careers, self-concept, locus of control, and English self-efficacy have also increased the odds of persistence in teaching aspirations by $46 \%, 38 \%$, and $12 \%$, respectively. Unlike other predictors, selfefficacy can be changed as a result of counseling interventions. This finding lends support to the socialcognitive theory in that contextual, experiential, and learning factors are mediated by the self-efficacy beliefs predicting career goal outcomes.

Given the importance of self-efficacy, interventions that are developed to build confidence and increase self-understanding of minority and male students are crucial. Betz (1992) suggested the following interventions to increase efficacy expectations: structuring performance accomplishments, observational learning, anxiety management, and verbal persuasion and encouragement. A career development program developed by O'Brien, Bikos, Flores, Dukstein, and Kamatuka (1996), based on the SCCT foundation, has shown to be promising in enhancing students' confidence in performing tasks related to investigating, selecting, and implementing a career choice. Counselors could use SCCT to design intervention programs that address the school, family, and psychological issues. Recognition of the relationship between these factors could aid counselors as they develop programs and plan interventions 
for their students. Given the unique contribution of self-efficacy in predicting teaching persistence, counselors need to take a proactive approach in tailoring developmentally appropriate and culturally sensitive career interventions for individuals from diverse cultural backgrounds.

The present study showed that only $33 \%$ of male students as compared to $44 \%$ of female students persisted in aspiring to teaching careers. Although the difference is not statistically significant, the disproportional representation of male teachers in addition to the lack of persistence in male participants in the teaching workforce raises an alarming concern. Sex role stereotyping may affect the survival rate of men in the pipeline (Seymour, 1995), as men may be concerned that they may lose their masculinity because teaching is tradition-ally perceived as a female job. For adolescent men, the pressures of trying to balance current and future gender relations in an environment that challenges conventional norms for men may create additional tensions and contradictions (McKinnon \& Ahola-Sidaway, 1995). Other factors, such as lower teacher expectations (Anderson, 1992) and lack of role models (Dryler, 1998; Nauta \& Kokaly, 2001), may also explain the loss of men in the teaching pipeline.

Overall, less than two fifths of the students aspiring to teaching careers maintained their aspirations 4 years later. The 10th grade students examined here were in the developmental stage when they were still exploring their career direction. It is likely that the majority of them changed their career goals when they encountered reality (Gottfredson, 1981). Considering that there was a smaller percentage of minority students, it seems important that those factors identified in the present study be incorporated into intervention pro-grams that would assist students to persist and eventually prevail in teaching careers.

The implications of this study are clear: Students' racial background and school environment are key factors of persistence in the teaching aspirations. Parents, teachers, and counselors must be aware of how these variables have affected their aspirations. Counselors could identify students who have teaching aspirations but are low in self-efficacy and help them to develop strategies for achieving their goals (Mau \& Bikos, 2000). It would appear that programs designed to encourage adolescent men and minority students to enter teaching careers need to be sensitive to the intimidation and subtle pressures they may face. Underrepresented men and minority students simply cannot be recruited into the teaching pipeline without continued support and encouragement. Informal support groups may be helpful in addressing the problems of young men and ethnic minority students who show an interest in teaching careers. Efforts to strengthen support systems and lessen barriers may better enable students to persist toward their career goals (R. W. Lent et al., 1996).

As is true of any study using general broad-based survey data, our study is limited to the survey questions available in the questionnaire. For example, because there was no specific measure of selfefficacy, we used locus of control and self-esteem to represent the self-efficacy construct. Additionally, some data analyses were based on one-item responses only. Thus, special attention needs to be given to the interpretation of the results. More research focusing on factors influencing persistence in teaching aspirations of men and ethnic minorities is needed. Further studies could include more rigorously calibrated measures. Knowledge generated from this type of research could further advance our understanding of the career development of these under-represented populations and factors leading to persistence in participation in the teaching workforce.

\section{References}

Anderson, B. T. (1992). Minority females in the science pipeline: Activities to enhance readiness, recruitment, and retention. Initiatives, 55(2), 31-38.

Bandura, A. (1986). Social foundations of thought and action: A social-cognitive theory. Englewood Cliffs, NJ: Prentice Hall.

Betz, N. E. (1992). Counseling uses of career self-efficacy theory. Career Development Quarterly, 41, 2226. 
Betz, N. E., \& Hackett, G. (1997). Application of self-efficacy theory to the career assessment of women. Journal of Career Assessment, 5, 383-402.

Cizek, G. J., \& Fitzgerald, S. M. (1999). Method, plainly speaking: An introduction to logistic regression. Measurement and Evaluation in Counseling and Development, 31, 223-245.

Cohen, J. (2005). AM statistical software. Washington, DC: American Institute for Research.

Curtin, T. R., Ingels, S. J., Wu, S., \& Heuer, R. (2002). NELS:88 base year to fourth follow-up data file user's manual (NCES 2002-323; U.S. Department of Education, National Center for Education Statistics). Washington, DC: U.S. Government Printing Office.

Dryler, H. (1998). Parental role models, gender and choice. British Journal of Sociology, 49, 195-209.

Farmer, H. S., Wardrop, J. L., Anderson, M. Z., \& Risinger, R. (1995). Women's career choices: Focus on science, math, and technology careers. Journal of Counseling Psychology, 42, 155-570.

Fouad, N. A., \& Smith, P. L. (1996). A test of a social model for middle school students: Math and science. Journal of Counseling Psychology, 43, 338-346.

Gottfredson, L. S. (1981). Circumscription and compromise: A developmental theory of occupational aspirations. Journal of Counseling Psychology, 28, 545-579.

Grissmer, D., \& Kirby, S. (1997). Teacher turnover and teacher quality. Teachers College Record, 99, 4556.

Hansen, J. C. (2005). Assessment of interests. In S. D. Brown \& R. W. Lent (Eds.), Career development and counseling: Putting theory and research to work (pp. 281-304). Hoboken, NJ: John Wiley.

Hanson, S. L. (1994). Lost talent: Unrealized educational aspirations and expectations among U.S. youths. Sociology of Education, 67, 159-183.

Henke, R. R., \& Zahn, L. (2001). Attrition of new teachers among recent college graduates: Comparing occupational stability among 1992-93 graduates who taught and those who worked in other occupations. Education Statistics Quarterly, 3, 69-76.

Holland, J. L. (1997). Making vocational choices: A theory of vocational personalities and work environments (3rd ed.). Odessa, FL: Psychological Assessment Resources.

Holland, P. W., \& Thayer, D. T. (1986). Differential item functioning and the Mantel-Haenszel procedure (ETS Research Report No. 86-31). Princeton, NJ: Educational Testing Services.

Ingersoll, R. M. (2001). Teacher turnover and teacher shortages: An organizational analysis. American Educational Research Journal, 38, 499-534.

Lee, J. B., Clery, S. B., \& Presley, J. B. (2001). Path to teaching. Edwardsville: Illinois Education Research Council, Southern Illinois University.

Lent, R. W. (2005). A social cognitive view of career development and counseling. In S. D. Brown \& R. W. Lent (Eds.), Career development and counseling: Putting theory and research to work (pp. 101130). Hoboken, NJ: John Wiley.

Lent, R. W., Brown, S. D., \& Hackett, G. (1996). Career development from a social-cognitive perspective. In D. Brown, L. Brooks, \& Associates (Eds.), Career choices and development (3rd ed., pp. 373416). San Francisco: Jossey-Bass.

Lent, W. L., Brown, S. D., \& Hackett, G. (1994). Toward a unifying social cognitive theory of career and academic interest, choice, and performance. Journal of Vocational Behavior, 45, 79-122.

Mau, W. C. (2003). Factor influencing persistence in science and engineering career aspirations. Career Development Quarterly, 51, 234-243.

Mau, W. C., \& Bikos, L. H. (2000). Educational and vocational aspirations of minority and Lent, W. L., Brown, S. D., \& Hackett, G. (1994). Toward a unifying social cognitive theory of career and academic interest, choice, and performance. Journal of Vocational Behavior, 45, 79-122.

Mau, W. C. (2003). Factor influencing persistence in science and engineering career aspirations. Career Development Quarterly, 51, 234-243. 
Mau, W. C., \& Bikos, L. H. (2000). Educational and vocational aspirations of minority and female students: A longitudinal study. Journal of Counseling and Development, 78, 186-194.

Mau, W. C., Domnick, M., \& Ellsworth, R. D. (1995). Characteristics of female students who aspire to science and engineering or homemaking careers. Career Development Quarterly, 43, 323-337.

McKinnon, M., \& Ahola-Sidaway, J. (1995). Workin' with the boys: A north American's perspective on nontraditional work initiatives for adolescent females in secondary schools. Gender and Education, 7, 327-339.

National Center for Educational Statistics. (1991). Psychometric report for the NELS:88: Base year test battery (Report No. 91-468). Washington, DC: U.S. Department of Education.

National Center for Educational Statistics. (1994). National educational longitudinal study, 1988: Second follow-up (1992) (Report No. 94-374). Washington, DC: U.S. Department of Education.

National Center for Educational Statistics. (1997). A note from the chief statistician: Technical approaches to performing regression and other multivariable techniques on NCES survey data (Notes No. 3). Washington, DC: U.S. Department of Education.

Nauta, M. M., \& Kokaly, M. L. (2001). Assessing role model influences on students' academic and vocational decision. Journal of Career Assessment, 9, 81-99.

O’Brien, K. M., Bikos, L. H., Flores, L. Y., Dukstein, R. D., \& Kamatuka, N. A. (1996, August). A career exploration program for Upward Bound students. In K. M. O’Brien \& M. J. Heppner (Chairs), Future directions in career counseling: Innovative interventions with special populations. Symposium conducted at the 1996 National Convention of the American Psychological Association, Toronto, Canada.

Page, J., Page, F., Hawk, J. D., Amburgey, B., \& Correro, G. (1980). The teaching profession. East Lansing, MI: National Center for Research on Teacher Learning. (ERIC Document Reproduction Service No. ED346082)

Page, J. A., \& Page, F. M., Jr. (1984). High school senior perception of teaching as a career opportunity. East Lansing, MI: National Center for Research on Teacher Learning. (ERIC Document Reproduction Service No. ED241534)

Schutz, P. A., Crowder, K. C., \& White, V. E. (2001). The development of a goal to become a teacher. Journal of Educational Psychology, 93, 229-308.

Seymour, E. (1995). The loss of women from science, mathematics, and engineering undergraduate majors: An explanatory account. Science Education, 79, 437-473.

Shen, J. (1997). Has the alternative certification policy materialized its promise? A comparison between traditionally and alternatively certified teachers in public school. Educational Evaluation and Policy Analysis, 17, 276-283.

Stroup, S. (2002). Teacher recruitment, preparation and development. Retrieved March 19, 2004, from http://www.ed.gov/Speeches/04-2002/20020424c.html

Super, D. E., Savickas, M. L., \& Super, C. M. (1996). The life-span life-space approach to careers. In D. Brown, L. Brooks, \& Associates (Eds.), Career choice and development (3rd ed., pp. 121-178). San Francisco: Jossey-Bass.

Tracey, T. J. G., Robbins, S. B., \& Hofsess, C. D. (2005). Stability and change in interests: A longitudinal study of adolescents from grades 8 through 12. Journal of Vocational Behavior, 66, 1-25.

U.S. Department of Education. (1999). Predicting the need for newly hired teachers in the United States to 2008-09 (NCES Report No. 1999-026 by William J. Hussar). Washington, DC: Author.

U.S. Department of Education. (2002). Meeting the highly qualified teachers challenge: The secretary's annual report on teacher quality. Washington, DC: Author.

Wilson, P. M., \& Wilson, J. R. (1992). Environmental influences on adolescent educational aspirations: A logistic transform model. Youth \& Society, 24, 52-70. 